\title{
Waqf Development in Indonesia: Challenges Faced by Muhammadiyah Waqf Institutions
}

\author{
Fahmi Medias \\ Universitas Muhammadiyah Magelang, Magelang, Indonesia \\ email: fahmimedias@ummgl.ac.id
}

\section{Eko Kurniasih Pratiwi}

Universitas Muhammadiyah Magelang, Magelang, Indonesia email: ekokurniasihpratiwi@ummgl.ac.id

\section{Khotibul Umam \\ Universitas Gadjah Mada, Yogyakarta, Indonesia \\ email: khotibulumam@ugm.ac.id}

\begin{abstract}
As a potential financial instrument, waqf has played an essential role in resolving the social problems of the society (ummah). Although Indonesia has long applied the existence of waqf, it has not had an impact on providing an optimal contribution to the welfare of the people. Several studies identified patterns of administration in the management of waqf. The purpose of this study aims to identify and explore the model of empowerment of Mahammadiyah waqf land in Magelang and its challenges in the development of the ummah. The study method used to collect data was descriptive qualitative and interviews, which covered the areas administered by the Mahammadiyah. About 78\% of these areas are empowered in the form of educational and worship facilities. However, it was observed that empowerment of the land in Magelang was not optimized due to lack of financial resources, unproductivity, and the presence of incompetent and professional Nazhirs. The solution to these problems is through collaboration with financial institutions in collecting cash equivalents, land specifications, formulating a special legal framework for empowering Muhammadiyah waqf, and training for the development of the capacity of the areas.
\end{abstract}

Keywords: Empowerment; Muhammadiyah waqf land; Magelang; Nazhir

\begin{abstract}
Abstrak: Sebagai instrumen finansial yang potensial, wakaf memiliki peran penting dalam menyelesaikan permasalahan sosial masyarakat (ummah). Meski keberadaan wakaf sudah lama diterapkan di Indonesia, namun belum berdampak pada memberikan kontribusi yang optimal bagi kesejahteraan masyarakat. Beberapa penelitian mengidentifikasi pola administrasi dalam pengelolaan wakaf. Tujuan penelitian ini adalah untuk mengidentifikasi dan mendalami model pemberdayaan lahan wakaf mahammadiyah di Magelang dan tantangannya dalam perkembangan umat. Metode penelitian yang
\end{abstract}

Economica: Jurnal Ekonomi Islam - Volume 10, Nomor 2 (2019) 
Fahmi Medias, Eko Kurniasih Pratiwi, and Khotibul Umam

digunakan untuk mengumpulkan data adalah deskriptif kualitatif dan wawancara meliputi wilayah-wilayah yang dikelola Mahammadiyah. Sekitar $78 \%$ dari wilayah tersebut diberdayakan dalam bentuk sarana pendidikan dan ibadah. Namun, teramati bahwa pemberdayaan tanah di Magelang belum optimal karena kurangnya sumber daya finansial, tidak produktif, dan adanya Nazhir yang tidak kompeten dan profesional. Solusi dari permasalahan tersebut adalah melalui kerjasama dengan lembaga keuangan dalam pengumpulan setara kas, spesifikasi tanah, penyusunan kerangka hukum khusus pemberdayaan wakaf Muhammadiyah, dan pelatihan pengembangan kapasitas daerah.

Kata Kunci: Pemberdayaan; Tanah wakaf Muhammadiyah; Magelang; Nazhir 
Waqf Development in Indonesia: Challenges ...

\section{Introduction}

Waqf plays an essential role in providing an endowment for the Ummah since it is an Islamic financial tool (Saifuddin et al. 2014; Medias 2015). Outstanding management ensures productiveness and be able to spur a country's social growth, as witnessed in several Muslim countries. Management of waqf in several Muslim countries has been carried out professionally and productively. For this reason, it is the primary solution for the development of the nation in the form of social instruments (Mohd Puad, Jamlus Rafdi, dan Shahar 2013; Fuadi 2018).

Attention to the development of waqf is also overgrowing in Indonesia. For instance, in 2019, the Ministry of Religion reported the total certified waqf land area to be $49,284.69 \mathrm{Ha}$, which is scattered in 368,242 different locations. However, this land is underused, which leaves a majority of it not being productive. Almost $44.72 \%$ of it is used for mosques development and 21.21\% utilized for mushollas. Click on the link for more on the waqf land http://siwak.kemenag.go.id/, and Figure 1 below illustrates the use of waqf land in Indonesia.

Figure 1. Use of waqf land in Indonesia

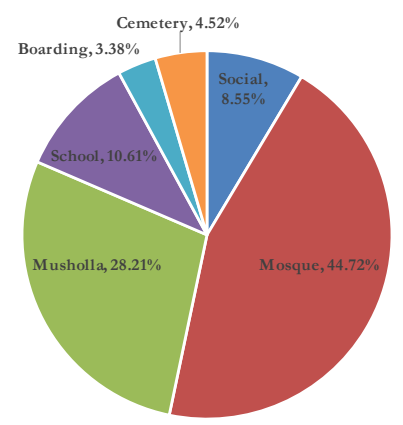

Source: Report on the use of waqf land for the Ministry of Religion of the Republic of Indonesia, 2019

Economica: Jurnal Ekonomi Islam - Volume 10, Nomor 2 (2019) 
Waqf management is undertaken by different levels in the society, including the Indonesian Waqf Board, community organizations (Nahdlatul 'Ulama and Muhammadiyah), private institutions, and individuals (Ministry of Religion of the Republic of Indonesia 2013). For instance, Muhammadiyah was the pioneer manager of the Indonesian waqf when his appointed was enacted in 1972 as waqf nazhir through Decree No. SK.14/DDA/1972 (Solihah, Mulyadi, dan Nur 2017). In the case of waqf administration, Muhammadiyah appoints the waqf and Martyrdom Council (MWK) at each level from the central, regional, and branch scale in Indonesia who are responsible for regulating and managing matters related exclusively to waqf (Yuristiadhi 2013).

According to the management report of Muhammadiyah Regional Leadership in Magelang in 2019, the waqf developed significantly in the last three years, recording endowment assets in cash amounting to Rp. 156 million Rupiah and the waqf land on expansive 415 fields (Medias dan Pratiwi 2019). Figure 2 below explains these findings.

Figure 2. Development of Muhammadiyah waqf in Magelang

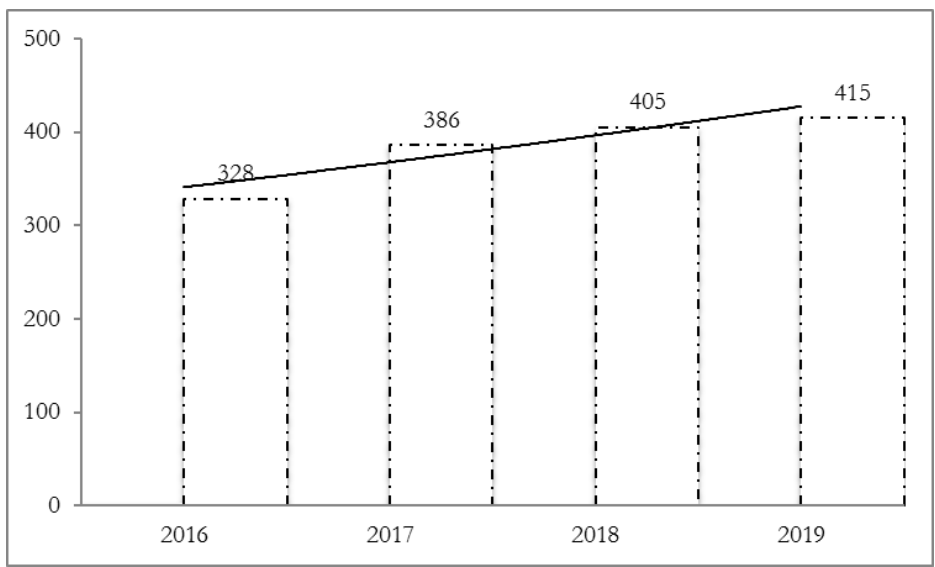

Source: MWK waqf management report, 2019 
Muhammadiyah waqf assets are quite extensive and have the potential to build a social community in the district of Magelang and improve human welfare in this area. However, there is still a lot of waqf land devoted to consumptive activities such as mosques, prayer rooms, and Islamic boarding schools.

Presently, the literature on Muhammadiyah waqf and its use has not been well developed and studied by many researchers, Solihah, Mulyadi, and Nur (2017). In managing waqf, nazhir needs to refer to the charity association concept used for religious, educational and economic facilities of the community. According to Bahri (2016), BP2RM (Muhammadiyah Branch Development Workers Agency), Pemalang provides good opportunities for residents in developing community-owned businesses. This shows good management system, as established by waqif and Nazir (Asy`ari 2017).

MWK as a waqf nazhir requires more in-depth focus in the context of the role it plays in the development of Ummah, especially in Magelang. The primary purpose of this article therefore is to analyze the challenges faced by Muhammadiyah waqf institution in developing the properties.

\section{Literature review}

This research relies on the fact that social and economic inequality has led to an increase in the poverty level in Indonesia, which is predominantly Muslim and rich in natural resources (Medias 2014). BPS (2018) studies revealed that the total number of people living below the poverty line reached $25.95 \%$ of the total population. However, this increase is not in line with natural resources. The main problem lies in the unequal distribution of wealth and the low principle of philanthropy among the people (Piliyanti 2010).

Gustina dan Ihsan (2010), established that in facing the Indonesian social justice crisis, the government needs to find alternative solutions in solving problems. The Indonesian government is further encouraged to learn

Economica: Jurnal Ekonomi Islam - Volume 10, Nomor 2 (2019) 
from Muslim countries such as Egypt, Bangladesh, Singapore, Turkey, and Saudi Arabia by developing Islamic instruments that uphold the principle of equal distribution of resources, one of which is waqf.

Bayinah (2012) said that if waqf is managed productively, it would have the potential for economic equality in Indonesia. For instance, if the majority of the Muslim community donated their assets in the form of cash waqf of one million per year per person, the resulting collection might be up to 20 trillion Rupiahs.

According to Rosalinda (2012) and Havita et al. (2013), if waqf is managed professionally and productively, it would undoubtedly act as a chain of Indonesia's economic potential. Waqf nazhir is obliged to develop waqf assets following Government Regulation Number 42 of 2006 Article 45 paragraph (1), which states that he may develop its assets in any form as long as it is lawful.

Waqf nazhir, can use Islamic financial instruments to improve its productivity following the government mandate Number 41 of 2004 regarding waqf, either by using a revenue-sharing agreement, buying and selling or leasing Mohsin (2012); Zuliansyah (2014). Other instruments according to Omar, Rahman, dan Mazlan (2013), include; investment, production, trade, real estate, supermarkets, shops, social facilities, education and health on the condition that it does not conflict with the shari'a.

Fauza (2015) encourages Indonesia to reflect on the success of Egypt and other Muslim countries in empowering waqf assets (Nagaoka 2015), health services such as hospital facilities and free medicines (Baharuddin dan Taufiq 2015), improvement of the social dynamics, providing a cover for the orphaned and the poor. To achieve this goal, waqf nazhir is obliged to set aside consumptive waqf assets into productive assets that increase the accumulation of benefits (Mohammad 2011). These benefits are then partly 
included in the costs of empowerment and investment, while others distributed to waqf recipients.

According to Department of Religious Affairs (2004) through Law No. 41 of 2004, the empowerment of waqf assets is directed towards the longterm independence of the community on advancement in education, economic growth, health and capital assistance for micro-enterprises (Abdul Latif, Nik Din, dan Mustapha 2018), (Shirazi 2014); and developing partnerships with other empowerment institutions (Huq dan Khan 2017).

Muhammad Anas Zarqa in Candra dan Rahman (2010) revealed that the economic goal of waqf assets is to generate profits, increase capital, and produce the desired benefits of the Ummah. For this reason, it is important to raise awareness about the significance of expanding waqf assets productively, either through development or investment, so that they can help improve the economic situation in Muslim societies, as achieved in the early history of Islamic civilization (Medias 2017).

Several researchers widely discussed waqf empowerment by nazhir Muhammadiyah. Damanuri (2012) Began with an analysis of the effectiveness and efficiency of waqf management in Ponorogo, from this study, established that evident that Muhammadiyah as Waqf nazhir collects both endless and immovable waqf assets which are integrated to buffer Muhammadiyah's businesses.

Yuristiadhi (2013) described Muhammadiyah as a philanthropic organization, which is in a position to manage waqf productively since it is a means of shared prosperity for the Ummah. However, according to Asy'ari (2016), this achievement requires the institution to have reliable human resources in managing the trust of the Ummah in the form of waqf assets.

Most of the studies focused on developing waqf assets. However, the challenges faced have not been deeply examined. Empowerment of waqf for 
social community development reveals how Muhammadiyah waqf nazhir manages and utilizes waqf assets.

These properties generate not only profits but also income to finance the development of waqf. The main goal of Muhammadiyah waqf institutions is to obtain social benefits for community objectives.

\section{Methods}

The study began by examining current references regarding the information on the number of waqf lands as well as their empowerment in Magelang. It then structured the instruments and indicators for use in waqf assets to help in the analysis and description of data. Afterwards, data was collected by survey method and interviews through FGD (Forum Group Discussion) it was validated and then analyze for the development of the Ummah in Magelang. The analysis flow is as explained in Figure 3 below:

Figure 3. Data analysis techniques

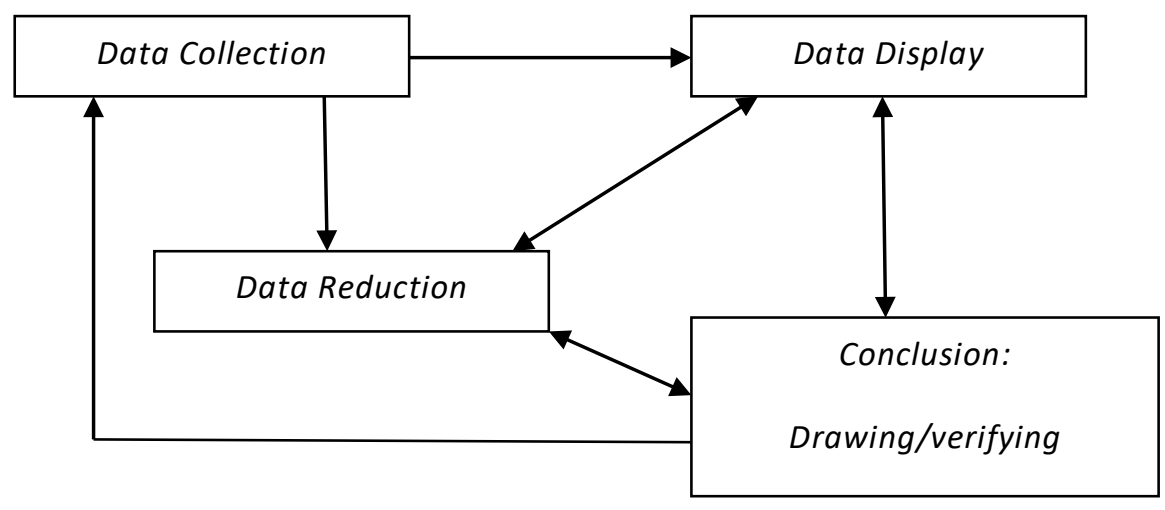


Waqf Development in Indonesia: Challenges ...

\section{Result and discussion}

The report reveals, MWK of Magelang has managed waqf assets in cash totalling 156 Million Rupiah, waqf land of 415 fields, 74\% worth of internal waqf assets, grants averaging at $6 \%$, purchases amounting to $13 \%$, and copyrights ranging at $7 \%$ of the total waqf assets.

Khairudin, the leader of the MWK of Magelang, admitted to having faced the following challenges: First, legal aspects. Regulations related to the development of Muhammadiyah waqf have not yet been owned explicitly by waqf nazhir. Due to the absence of these regulations, several parties are not responsible for misuse of Muhammadiyah's waqf resources. Waqf nazhir only emphasizes aspects of the administration of waqf asset.

Muhammadiyah is therefore expected to formulate more comprehensive rules for the development of waqf assets, which are in line with the Law No. 41 of 2004 and Government Regulation No 42 of 2006 concerning the implementation of waqf. For this reason, there is a need for the approval of essential rules regarding Muhammadiyah waqf.

Second, inadequate funds for development empowerment of waqf assets have been affected by the inadequacy of funds, especially for investment. Most of the waqf assets are mosques and educational institutions which provide minimal benefit to the Ummah. It is, therefore, necessary to invest in it to keep the role and power of Muhammadiyah's waqf afloat.

Various solutions should be considered, for instance, financial schemes and instruments that are appropriate for empowering waqf assets in Magelang to further benefit the socio-economic community. Also, programmes can be combined in the form of mudhaarabah or mushaarakah with financial institutions as Islamic commercial entities in Indonesia.

Third, the waqf land is not productive. Traditionally, Muhammadiyah assets are located in rural areas, where it is quite difficult to establish them.

Economica: Jurnal Ekonomi Islam - Volume 10, Nomor 2 (2019) 
The inadequacy of the assets for empowerment is evidenced by the fact that more than $78 \%$ of it is allocated for religious and educational needs, as shown in Figure 5:

Figure 5. Allotment of Muhammadiyah waqf assets

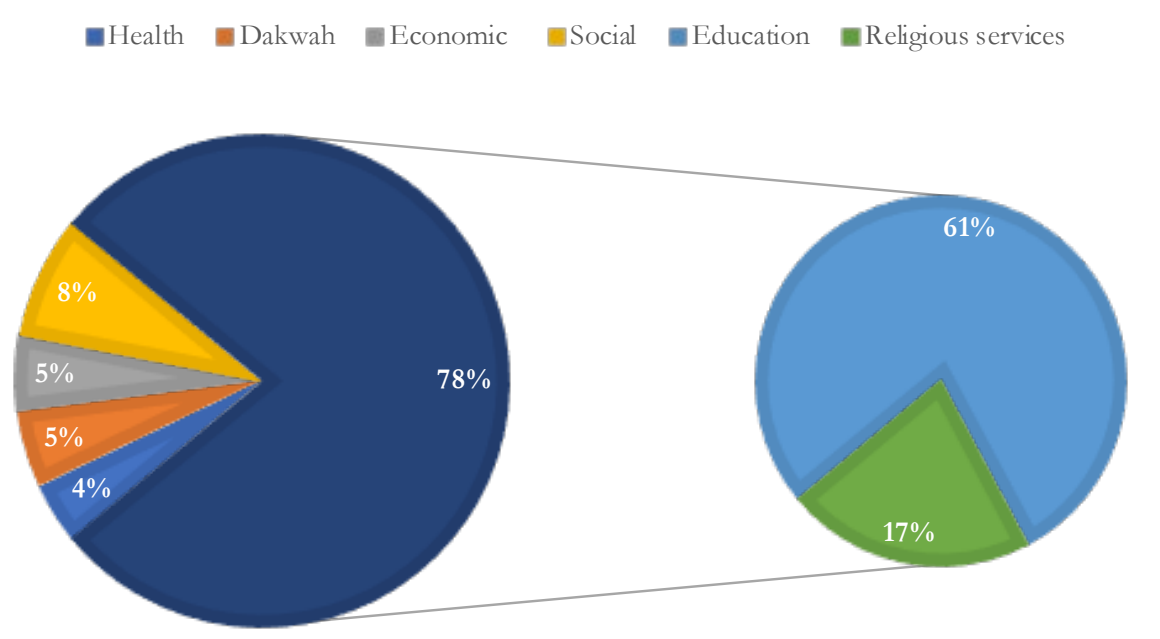

Source: PDM Management Report for Magelang, 2019

From Figure 5, the empowerment of Muhammadiyah waqf assets in Magelang has not been optimized professionally and productively to be able to achieve its potential. The solution lies in reviving unutilized waqf land through the concept of Istibdal.

Fourth, Muhammadiyah waqf nazhir lack knowledge and competence, which is greatly needed for the prosperity of Ummah. Currently, the objective condition in Muhammadiyah waqf is that nazhir activities are still limited in asset maintenance, without having the vision and ability to develop them to be more productive. In other words, the current image of Muhammadiyah's waqf in Magelang currently indicates that its primary responsibility is to take care of the land, which results in no plan to develop these assets. MWK 
should, therefore, provide professional training to Nazir at both regional and branch levels.

Lita (2018) states that proper waqf management is an essential factor that contributes to the successful development of assets. Therefore, there is a need to determine the gap between the existing waqf asset management practices and development projects in Magelang. The difference is expected to be able to increase management knowledge and future experience.

Problems that are faced such as the legal basis for empowerment, source of empowerment funds, unproductive land, and nazhir expertise in empowering Muhammadiyah waqf assets in Magelang contribute to the inefficiency of waqf management in Magelang. This is a significant hindrance for waqf nazhir in achieving waqf goals that are beneficial to the Ummah. Therefore, it requires a follow-up plan to make waqf assets more productive.

Waqf assets should be monitored and maintained for future generations. Mohd Puad, Jamlus Rafdi, dan Shahar (2013) urges basic principles which guide empowerment of waqf assets, provide accurate data to the public regarding the management of waqf assets and improve the efficiency and effectiveness of their use. Besides, Muhammadiyah waqf nazhir must be able to identify waqf assets that have the potential and are suitable to be developed to provide benefits to the Ummah (Abdul Karim 2010).

There is a need for alternative means of development to be further explored by Muhammadiyah Regional Leaders of Magelang in the asset empowerment program. The Muhammadiyah tarjih fatwas given need to be pro-active by considering contemporary issues related to waqf empowerment. Since not all Muslims have movable assets to hand over as waqf, the creation of a cash waqf scheme opens up more extensive opportunities to develop waqf assets (Pitchay et al. 2018; Candra dan Rahman 2010).

Economica: Jurnal Ekonomi Islam - Volume 10, Nomor 2 (2019) 
Problems experienced in the empowerment of Muhammadiyah waqf land should be a consideration for MWK to initiate a project in future which can make the land useful for Muslim and non-Muslim communities in Magelang. Also, the process of empowering waqf land should not only be limited to education or worship facilities. More benefits will come out of these projects if economic development and investment are implemented.

\section{Conclusion}

From this study, Muhammadiyah waqf land in Magelang has not yet been endowed. The empowerment model currently seems ineffective in generating sufficient funds to develop the socio-economic community, since $78 \%$ of the existing waqf land is empowered in the form of educational facilities and religious facilities that do not produce economic benefits.

The ineffective empowerment of waqf land is inseparable from problems and challenges which cripples any attempts to put it on track. These challenges include financial resources, undeveloped and unproductive waqf land, legal framework, and the existence of incompetent and unprofessional Nazir. Because of these constraints, the MWK of Magelang needs further steps, a more effective and comprehensive approach to increase waqf investment in the future.

Thus, it needs to play its role effectively and ensure that waqf assets are used to increase social stability, especially in efforts to eradicate poverty for the welfare of Muslims. Therefore, a comprehensive investment plan is required for short term and long term.

\section{References}

Abdul Karim, Shamsiah. 2010. "Contemporary Shari'a Compliance Structuring for the Development and Management of Waqf Assets in Singapore." Kyoto Bulletin of Islamic Area Studies 3 (2): 143-64. 
Abdul Latif, Saripah, Nik Muniyati Nik Din, dan Zaiton Mustapha. 2018. "The Role of Good Waqf Governance in Achieving Sustainable Development." Environment-Behaviour Proceedings Journal 3 (7): 113-18. https://doi.org/10.21834/e-bpj.v3i7.1292.

Asy`ari, Muharrir. 2017. "Problematika Tata Kelola Wakaf Di Lingkungan Muhammadiyah Aceh." Jurnal Ilmiah Islam Futura 16 (1): 32. https://doi.org/10.22373/jiif.v16i1.742.

Baharuddin, Gunawan, dan Bayu Taufiq. 2015. "The Emergence of Waqf Bank: A Social welfare Alternative in Indonesia." In Advanced Course on Social and Ecological Market Economy, 31-39.

Bahri, Amirul. 2016. "Peranan Wakaf Produktif Pemuda Muhammadiyah Untuk Kesejahteraan Warga Desa Longkeyang, Bodeh, Pemalang." Indonesian Journal of Islamic Literature and Muslim Society 1 (2): 199. https://doi.org/10.22515/islimus.v1i2.499.

Bayinah, Nur. 2012. "Exploring and Empowering Waqf Invesment Toward an Acceleration of Economic." In Conference Proceedings Annual Internasional Conference on Islamic Studies (AOCIS XI), 2681-2707.

BPS. 2018. "Profil Kemiskinan di Indonesia."

Candra, Hari, dan Asmak Ab Rahman. 2010. "Waqf Investment: A Case Study of Dompet Dhuafa Republika, Indonesia." Jurnal Syariah 18 (1): 163-90.

Damanuri, Aji. 2012. "Efektivitas dan Efisiensi Pemanfaatan Harta Wakaf Majlis Wakaf Pimpinan Daerah Muhammadiyah Ponorogo." Kodifikasia 6 (1): 77-98.

Departemen Agama RI. 2004. Undang-Undang No. 41 tentang Wakaf.

Fauza, Nilna. 2015. "Rekonstruksi pengelolaan wakaf: belajar pengelolaan wakaf dari bangladesh dan malaysia." Universum 9 (2): 161-72.

Fuadi, Nasrul Fahmi Zaki. 2018. "Wakaf sebagai Instrumen Ekonomi Pembangunan Islam." Economica: Jurnal Ekonomi Islam 9 (1): 151. https://doi.org/10.21580/economica.2018.9.1.2711.

Gustina, dan Hidayatul Ihsan. 2010. "Integrating Islamic Banking, Zakat And Waqf With Islamic Microfinance In Poverty Alleviation." Jurnal Akuntansi \& Manajemen Vol 5: 45-52.

Havita, Gusva, Kartika Arum Sayekti, Silvia Ranny Wafiroh, Ilmu Hukum, Fakultas Hukum, Universitas Indonesia, Fakultas Ekonomi, et al. 2013.

Economica: Jurnal Ekonomi Islam - Volume 10, Nomor 2 (2019) 
“Model Bank Wakaf Di Indonesia Dalam Potensinya Untuk." Program Kreatifitas Mahasiswa - Gagasan Tertulis.

Huq, M Azizul, dan Foyasal Khan. 2017. "The Role of Cash Waqf in The Development of Islamic Higher Education in Bangladesh." Journal of Islamic Economics, Banking and Finance 13 (4): 45-65. https://doi.org/10.12816/0051001.

Kementrian Agama RI. 2013. Pedoman Pengelolaan dan Perkembangan Wakaf. I. Jakarta: Direktorat Pemberdayaan Wakaf.

Lita, Helza Nova. 2018. "The Construction of Commercial Building on Waqf Land Based on Indonesia Law." IOP Conference Series: Earth and Environmental Science 175 (1): 1-4. https://doi.org/10.1088/17551315/175/1/012199.

Medias, Fahmi. 2014. "Rekonstruksi Manajemen Dana Wakaf Pada Lembaga Wakaf Di Indonesia." Cakrawala IX/No. 2 (41): 1-15.

———. 2015. "Paradigma Baru Manajemen Wakaf.pdf." Jurnal Pemikiran Islam RASAIL Vol. I (2): 21-43.

——_. 2017. "Bank Wakaf: Solusi Pemberdayaan Sosial Ekonomi Indonesia." Indonesian Journal of Islamic Literature and Muslim Society 2 (1): 61-84. https://doi.org/10.22515/islimus.v2i1.749.

Medias, Fahmi, dan Eko Kurniasih Pratiwi. 2019. "The Evaluation of Muhammadiyah Waqf Asset Utilisation in Magelang." IQTISHADIA 12 (1): 101-18. https://doi.org/10.21043/iqtishadia.v12i1.3208.

Mohammad, Mohammad Tahir Sabit Haji. 2011. "Towards an Islamic Social (Waqf) Bank." International Journal of Trade, Economics and Finance 2 (5): 381-86. https://doi.org/10.7763/IJTEF.2011.V2.135.

Mohd Puad, Noor Aimi Bt, Nurauliani Bt Jamlus Rafdi, dan Wan Shahdila Shah Bt Shahar. 2013. "Issues and Challenges of Waqf Instrument: a Case Study in Mais." Journal of Chemical Information and Modeling 53 (9): 1689-99. https://doi.org/10.1007/s13398-014-0173-7.2.

Mohsin, Madga Ismail. 2012. "Waqf-shares : new product to finance old waqf properties." Bank and Bank Systems 7 (2): 72-78.

Nagaoka, Shinsuke. 2015. "Revitalization of the traditional Islamic economic institutions (waqf and zakat) in the twenty-first century: Resuscitation of the antique economic system or novel sustainable system?" In Access 
Waqf Development in Indonesia: Challenges ...

to Finance and Human Development - Essays on Zakah, Awqaf and Microfinance, 1:1-112.

Omar, Hydzulkifli Hashim, Asmak Ab Rahman, dan Ahmad Rizal Mazlan. 2013. "The Structuring for Development and Management Waqf Properties in Malaysia." Journal of Human Development and Communication 2 (June): 45-59.

Piliyanti, Indah. 2010. "Transformasi Tradisi Filantropi Islam: Studi Model Pendayagunaan Zakat , Infaq , Sadaqah Wakaf di Indonesia." Economica II (II): 1-14.

Pitchay, Anwar Allah, Mohamed Asmy Mohd Thas Thaker, Al Amin Mydin, Zubir Azhar, dan Abdul Rais Abdul Latiff. 2018. "Cooperative-waqf model: a proposal to develop idle waqf lands in Malaysia." ISRA International Journal of Islamic Finance 10 (2): 225-36. https://doi.org/10.1108/IJIF-07-2017-0012.

Rosalinda. 2012. "Peran Wakaf dalam Pemberdayaan Ekonomi Perempuan 38." Kafa`ah: Journal of Gender Studies Vol 2 (1): 38-62.

Saifuddin, Farhah, Saim Kayadibi, Refik Polat, Yahya Fidan, dan Omer Kayadibi. 2014. "The Role of Cash Waqf in Poverty Alleviation: Case of Malaysia." In Kuala Lumpur International Business, Economics and Law Conference 4 (KLIBEL4), 1:272-89.

Shirazi, Nasim Shah. 2014. "Integrating Zakāt and Waqf into the Poverty Reduction Strategy of the IDB Member Countries." Islamic Economic Studies 22 (1): 79-108. https://doi.org/10.12816/0004131.

Solihah, Cucu, Dedi Mulyadi, dan Hilman Nur. 2017. "Muhammadiyah Nazhir Organization Analysis of Waqf Management and Development in Cianjur." Jurnal Dinamika Hukum 17 (2): 125. https://doi.org/10.20884/1.jdh.2017.17.2.702.

Yuristiadhi, Ghifari. 2013. “Tentang Agraria, Filantropi dan Modernitas: Pengelolaan Wakaf Produktif Muhammadiyah di Yogyakarta 1960an2000an." In The First Graduate Workshop and Seminar of Local History, $1-11$.

Zuliansyah, A. 2014. "Optimalisasi Pemberdayakan Wakaf Upaya Mensejahterakan Umat.” Jurnal Asas 5 (2): 13.

Economica: Jurnal Ekonomi Islam - Volume 10, Nomor 2 (2019) 
Fahmi Medias, Eko Kurniasih Pratiwi, and Khotibul Umam 